\title{
Effects of chrysotile and acid-treated chrysotile on macrophage cultures
}

\author{
E. G. BECK, P. F. HOLT and E. T. NASRALLAH \\ Medizinisches Institut für Lufthygiene und Silikoseforschung an der Universität Düsseldorf, \\ and the Department of Chemistry, University of Reading, Berkshire
}

\begin{abstract}
Beck, E. G., Holt, P. F., and Nasrallah, E. T. (1971). Brit. J. industr. Med., 28, 179-185. Effects of chrysotile and acid-treated chrysotile on macrophage cultures. The addition of chrysotile asbestos to monolayer cultures of peritoneal and alveolar macrophages produces an increase in membrane permeability, as measured by eosin uptake and lactic dehydrogenase activity of the supernatant fluid. The lactate synthesis is increased, however. It is suggested that the permeability of the cell membrane is increased while dust particles are being phagocytosed, which may take several hours when the particles are fibrous, but that this does not imply cell damage.

Treatment of chrysotile with acid, which leaves a silica surface, results in a product that reduces lactate synthesis, implying cytotoxicity. This change is counteracted by poly(2-vinylpyridine 1-oxide). The polymer does not affect the properties of the native chrysotile.
\end{abstract}

Quartz particles that have been inhaled are phagocytosed by macrophages in the lung. The particles exert a cytotoxic effect and pulmonary fibrosis follows the death of macrophages. Macrophage cultures have been used to study the cytotoxicity of quartz and the ability of certain organic polymers to counteract its toxicity. Three tests that may be used are (1) the viability test, in which the uptake of acid dyes by macrophages is determined, (2) the estimation of lactic dehydrogenase (LDH) activity in the culture fluid, and (3) measurement of the rate of lactate synthesis by the cells.

If a substance exerts a toxic effect on a cell, the cell membrane becomes more permeable so that acid dyes will pass into the cell and enzymes are released (Beck, 1968); decreased metabolism is shown by a decrease in the rate of lactate synthesis. An inert dust (e.g., corundum) affects viability and LDH values only slightly and it increases the rate of lactate synthesis because the work done in phagocytosing the particles increases the metabolic rate (Beck, 1968). Beck, Bruch, and Brockhaus (1963) showed that poly(2-vinyl-pyridine 1-oxide) (PVNO) reduced or even abolished the cytotoxic action of quartz particles on macrophage cultures.

The published results on the effects of asbestos on cell cultures are confusing. Beck, Sack, and Bruch (1967b) found no cytochemical, optical or electron microscopical evidence of cell damage when chrysotile and other types of asbestos were incubated with mouse fibroblasts. Sack (1967), who used monolayer cultures of mouse fibroblasts (cell-line L), and peritoneal macrophages from the guinea-pig, and Beck (1970), who used alveolar macrophages from the guinea-pig, were unable to show any certain cytotoxic effects when asbestos was added although some differences were observed. Pernis, Vigliani, Marchisio, and Zanardi (1966) found no damage to mouse fibroblasts (cell-line L), KB-cells, and peritoneal macrophages of guinea-pigs, and no effect on the metabolic activity of the cells as judged by lactate production.

However, Parazzi, Pernis, Secchi, and Vigliani (1968) found that three methods (loss of fluorochromasia, LDH activity, and lactate production) agreed in showing that chrysotile and crocidolite 
asbestos have a strong and rapid cytotoxic action on macrophages. Koshi, Hayashi, and Sakabe (1968) obtained confusing results: some asbestos samples affected macrophage cultures, others did not.

This paper describes the effects of chrysotile asbestos on cultures of peritoneal and alveolar macrophages as judged by the viability, LDH, and lactate tests. The effects of chrysotile that had been modified by treatment with acid were also examined. This acid-treated asbestos and the original sample were treated with PVNO and further tests were made with these samples.

In treating the chrysotile with PVNO, the object was to deposit a complete monolayer of the polymer on the asbestos surface. With this object, the adsorption of the polymer on asbestos and the acid-treated asbestos was studied.

\section{Materials}

Dusts

A high-grade Rhodesian chrysotile that had been opened in the mill of a dust tunnel (Holt, Mills, and Young, 1964) was used. For the adsorption measurements part of this sample was allowed to stand in water and another part in $0.1 \mathrm{~m}$ hydrochloric acid for one week. The quartz sample was the commercially available Dörentruper powdered crystal quartz DQ 12 , specific surface $5.7 \mathrm{~m}^{2} / \mathrm{g}$, particle size $<3 \mu \mathrm{m}$.

The control dust was the commercially available corundum $\left(\mathrm{Al}_{2} \mathrm{O}_{3}\right)$ Maxalun, specific surface $1.5 \mathrm{~m}^{2} / \mathrm{g}$, average particle size $3 \mu \mathrm{m}$.

\section{Methods}

Adsorption of PVNO on chrysotile and acid-extracted chrysotile

Stoppered tubes, each containing $0.1 \mathrm{~g}$ of asbestos and $20 \mathrm{ml}$ of various concentrations of an aqueous solution of the polymer, were shaken in a thermostat for 24 hours at $25^{\circ} \mathrm{C}$. The contents of the tubes were then filtered. The concentrations of the polymer in the filtrates were determined by measuring the ultraviolet absorption at $260 \mathrm{~nm}$. The weights of polymer adsorbed at each concentration were plotted against the weights of polymer in the original solutions (Fig. 1).

On the basis of these results, the polymer-coated chrysotile and acid-extracted chrysotile used in the cell tests were prepared by equilibrating $1 \mathrm{~g}$ of asbestos with $0.4 \mathrm{~g}$ of PVNO in $200 \mathrm{ml}$ of water, this being more than that required to produce a monolayer.

\section{Cell tests}

Monolayer cultures of guinea-pig peritoneal and alveolar macrophages were prepared by the technique described by Beck $(1968 ; 1970)$. The macrophages were collected in NCTC 109 medium (Disco Laboratories, Detroit, Michigan) and cooled in an ice-bath. The cells in the pool were counted in a haemocytometer and aliquots of the culture were transferred to Leighton tubes (Fig. 2). Each tube contained 4 to $5 \times 10^{6}$ cells. The contents of the tubes were incubated at $37^{\circ} \mathrm{C}$. After one hour when the cells had become attached to the bottom of the tube,

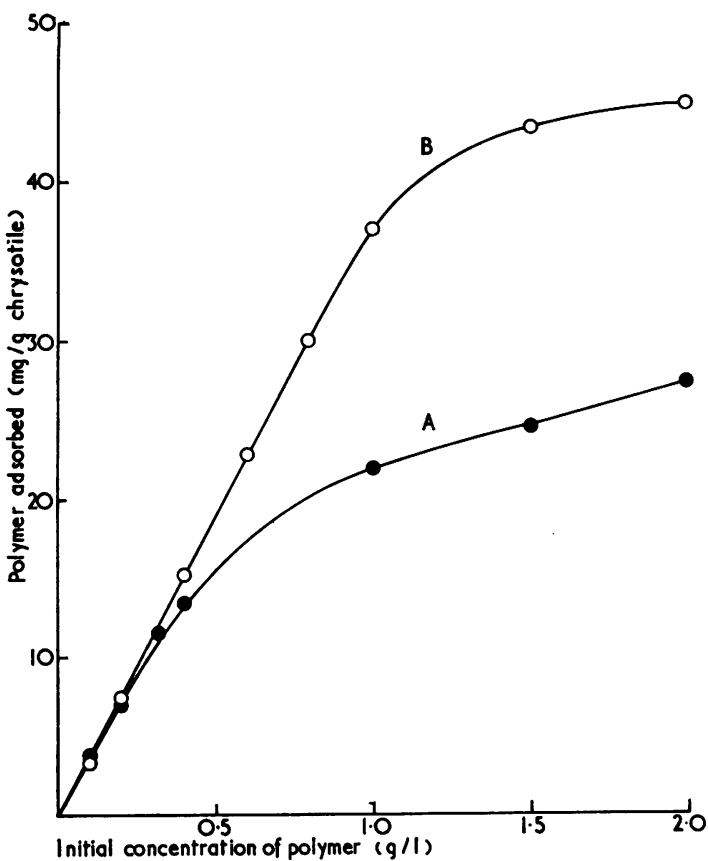

FIG. 1. Adsorption isotherms of poly(2-vinylpyridine 1-oxide) on (A) water-extracted and (B) acid-extracted chrysotile.

the dust sample suspended in culture medium was added in a concentration of $150 \mu \mathrm{g}$ of dust per $10^{6}$ cells.

Control experiments in which quartz, corundum or no dust was added were run simultaneously with each group of tests. LDH was determined by the method of Wieland and Pfleiderer (1957) and lactate enzymatically by the method of Horn and Bruns (1956).

In each series of experiments the fluid from a tube was collected 3, 6, and 20 hours after the addition of a dust. After the same intervals the cells on the cover-slips in the Leighton tubes were stained with eosin-Y (Hanks and Wallace, 1958) and examined under the microscope to determine the proportion of cells stained. Cells in parallel tubes were observed by phase contrast microscopy. Identical values cannot be obtained in repetitive biological tests: each value in the table represents the average of four experiments.

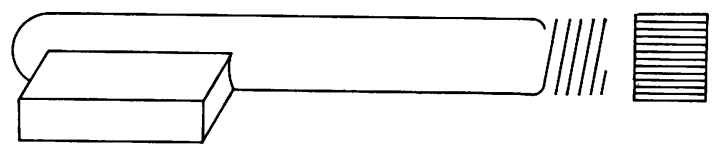

FIG. 2. The Leighton tube is a screw-capped test tube having a rectangular enlargement in the wall at the closed end which retains the medium and allows direct microscopic observation. 


\section{Results}

\section{Adsorption of PVNO on chrysotile and acid-washed chrysotile (Fig. 1)}

The adsorption relevant to acid-washed chrysotile was linear until $40 \mathrm{mg}$ PVNO per $\mathrm{g}$ chrysotile was adsorbed; then there was a sharp break where, presumably, a monolayer was formed. The material that had not been treated with acid behaved differently in that the early part of the curve was not linear and the break was less sharp. The weight of polymer adsorbed at the break in the curve was about half that adsorbed on the acid-washed sample, i.e., about $23 \mathrm{mg}$ per $\mathrm{g}$ chrysotile.

Cell tests: peritoneal macrophages (Table; Figs. 3 and 4)

The 'inert' control dust (corundum) had little effect on the permeability of the cell wall as measured by the viability and LDH tests. The metabolism, as measured by rate of lactate synthesis, was increased.

The addition of quartz produced a very large increase in LDH activity and in the uptake by the cells of eosin-Y, $99 \%$ of the cells being stained after 20 hours. There was a pronounced fall in lactate synthesis.

When chrysotile was added to a culture, increases in eosin-Y uptake and LDH activity after 20 hours were observed. There was, however, an increase in lactate synthesis. Chrysotile that was treated with PVNO resembled the untreated chrysotile in its effects on cultures; there were similar increases in eosin-Y uptake by the cells, LDH activity and lactate synthesis after 20 hours. Pre-treatment of the chrysotile with acid increased the eosin-Y uptake by two to three times, considerably increased the LDH values, and reduced lactate synthesis. The acidtreated chrysotile with adsorbed PVNO gave values for lactate synthesis which were similar to those given by untreated chrysotile with adsorbed PVNO, however.

Cell tests: alveolar macrophages (Table; Figs. 5 and 6)

The effect of quartz on the alveolar macrophages was similar to that on peritoneal macrophages: after 20 hours $99 \%$ of the cells were stained by eosin-Y, the LDH activity in the culture medium was largely increased, and the lactate production was largely decreased. Chrysotile increased the eosin-Y uptake to a larger extent than it did with peritoneal macrophages and increased the LDH activity but it also increased the lactate production. Treatment of the chrysotile with PVNO did not greatly change its effects on the cultures, although phagocytosis was increased. The acid-treated chrysotile, however, produced a larger increase in the membrane permeability of the cells (eosin- $Y$ uptake and $\mathrm{LDH}$ values) than did untreated chrysotile. The lactate production was also largely decreased. When the acid-treated material was coated with PVNO, the values of the viability and lactate tests

TABLE

Effects of Certain Dusts on Cultures of Macrophages: Mean (Ranges in Parentheses)

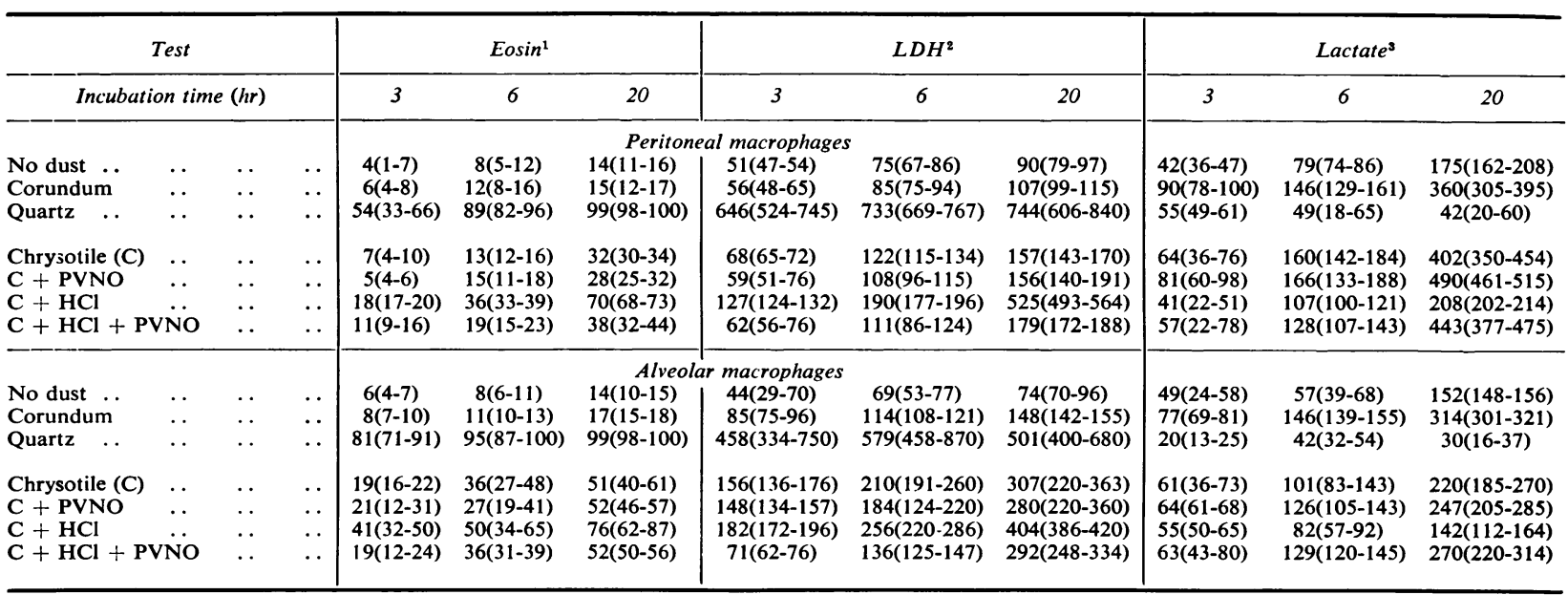

${ }^{1}$ Cells stained by eosin-Y $(\%)$.

${ }^{2} \mathrm{LDH}$ activity in culture fluid $(\mathrm{mU})$

${ }^{3}$ Lactate synthesis $(\mu \mathrm{g})$.

Each experiment was run in quadruplicate. The same culture was used for all these tests. 


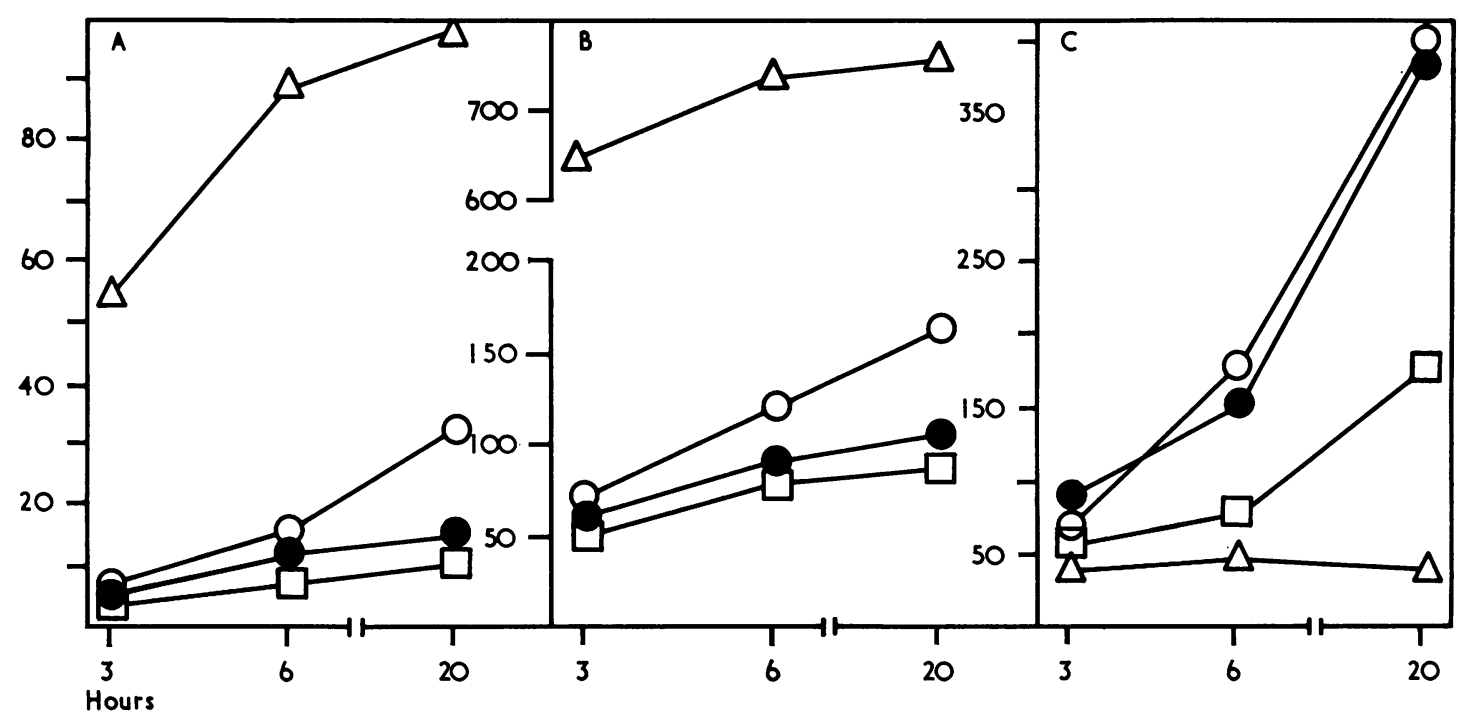

FIG. 3. Effects of dusts on guinea-pig peritoneal macrophages: $\square$ control; $\triangle$ quartz; corundum; $\bigcirc$ chrysotile. (A) Cells stained by eosin (\%); (B) LDH activity (mU/4 $\times 10^{6}$ cells); (C) lactate production $\left(\mu \mathrm{g} / 4 \times 10^{6}\right.$ cells).

were not significantly different from the values obtained with untreated chrysotile.

\section{Comment}

The fibrogenesis which is the characteristic effect of silica in the lungs follows the damage or the death of macrophages that have ingested silica particles The toxicity of silica has been studied with marked success by the use of cell cultures. Cells cultured in vitro, especially mammalian, peritoneal, and alveolar macrophages which have ingested silica

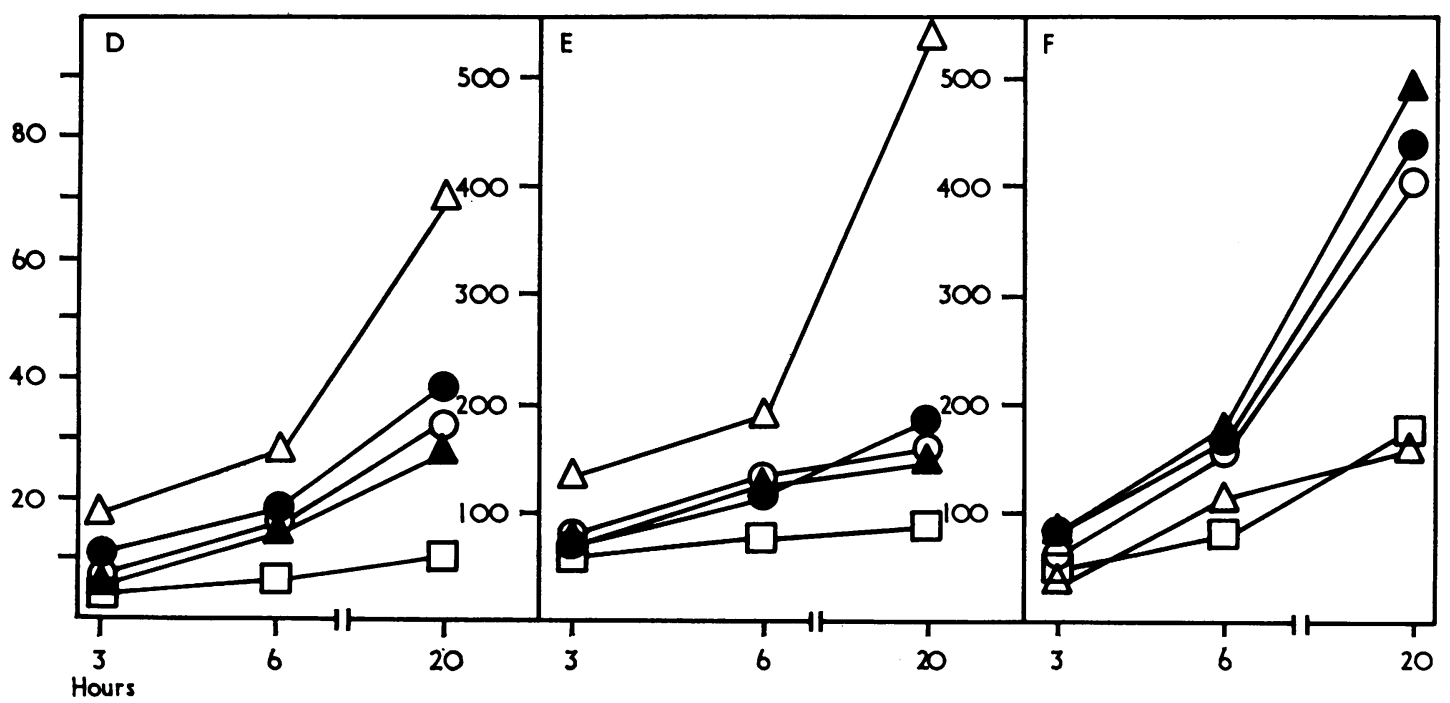

FIG. 4. Effects of dusts on guinea-pig peritoneal macrophages: $\square$ control; $\bigcirc$ chrysotile; $\Delta$ chrysotile + PVNO; $\triangle$ acid-treated chrysotile; acid-treated chrysotile + PVNO. (D) Cells stained by eosin (\%); (E) LDH activity $\left(\mathrm{mU} / 4 \times 10^{6}\right.$ cells); (F) lactate production $\left(\mu \mathrm{g} / 4 \times 10^{6}\right.$ cells). 


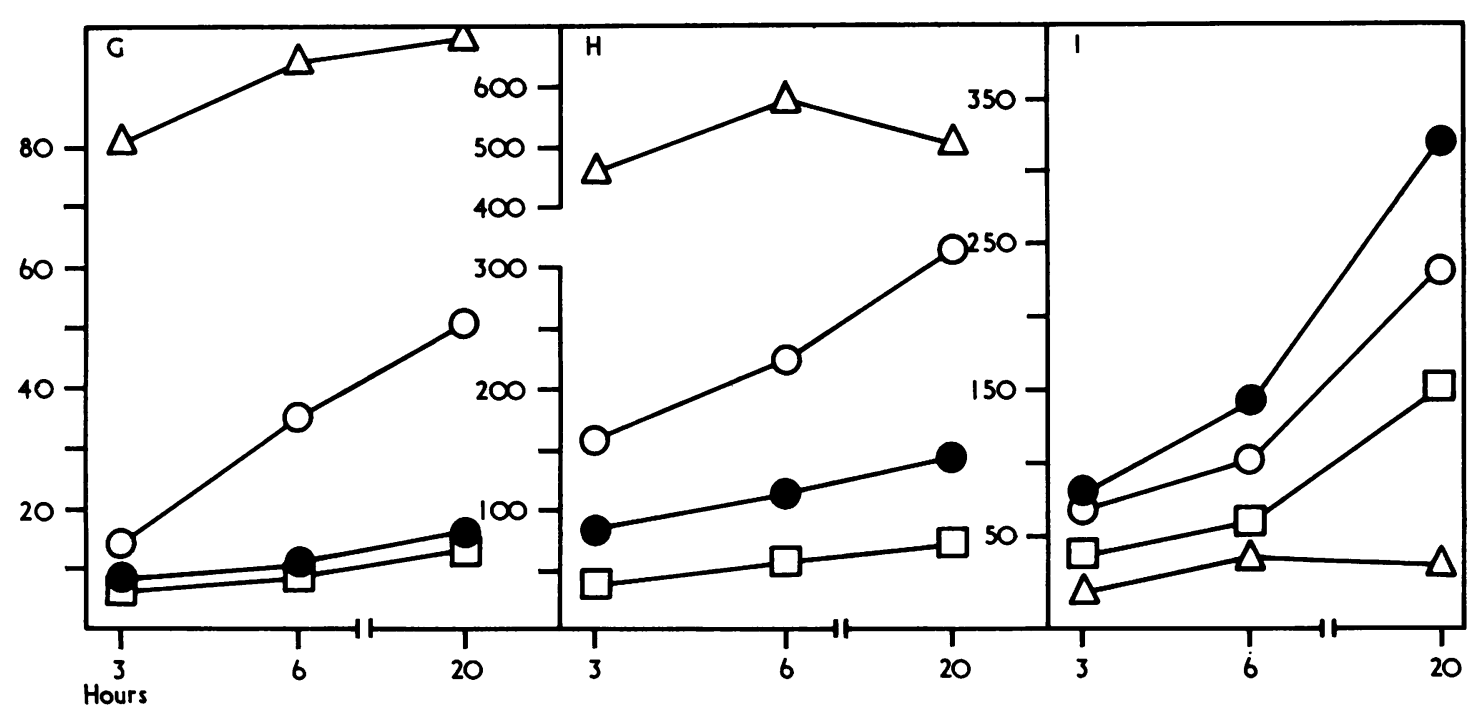

FIG. 5. Effects of dusts on guinea-pig alveolar macrophages: $\square$ control; $\triangle$ quartz; $\bullet$ corundum; $\bigcirc$ chrysotile. (G) Cells stained by eosin (\%); (H) LDH activity (mU/4 × $10^{6}$ cells); (I) lactate production $\left(\mu \mathrm{g} / 4 \times 10^{8}\right.$ cells).

particles, show vacuolization of cytoplasm, rounding of the cell shape, and finally the destruction of the cell with pyknosis of the nucleus and disintegration of the cellular membrane. One of the first signs of the toxicity of silica is the alteration in the permeability of the cell membrane which can be estimated by a number of methods: eosin-Y stains damaged cells, enzymes leak from the cells into the supernatant fluid, and metabolic activity is depressed, as is apparent in a reduction in the rate of lactate synthesis. Phase contrast microscopy is especially convenient for demonstrating the cytotoxic action of

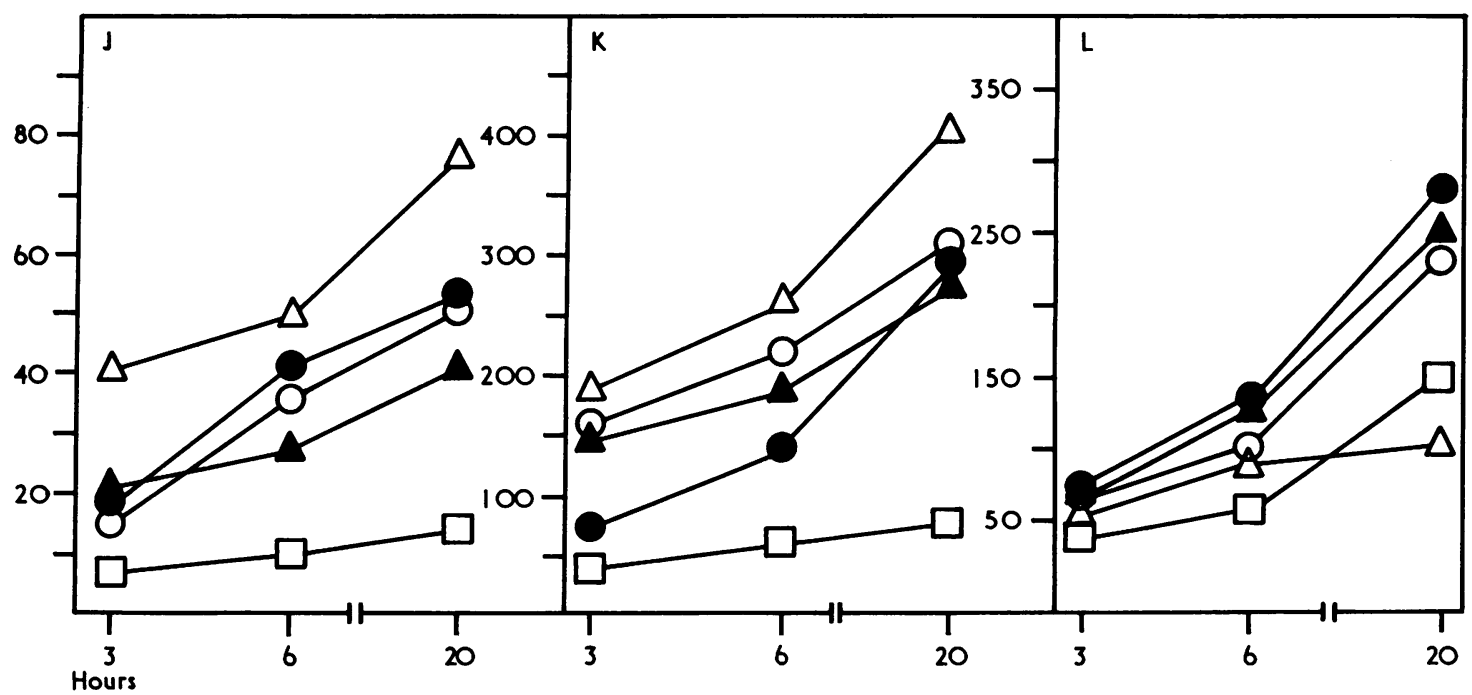

FIG. 6. Effects of dust on guinea-pig alveolar macrophages: $\square$ control; $\bigcirc$ chrysotile; $\Delta$ chrysotile + PVNO; $\triangle$ acid-treated chrysotile; acid-treated chrysotile + PVNO. (J) Cells stained by eosin (\%); (K) LDH activity $\left(\mathrm{mU} / 4 \times 10^{6}\right.$ cells $) ;(\mathrm{L})$ lactate production $\left(\mu \mathrm{g} / 4 \times 10^{6}\right.$ cells $)$.

4 
silica, and it also clearly shows the intact appearance of the PVNO-protected cells.

Previous attempts to answer the question whether chrysotile asbestos has similar cytotoxic action to quartz have led to anomalous results. In the earlier experiments of Beck and his colleagues (1967b)and of Sack (1967), monolayer cultures of peritoneal macrophages showed no acute cell damage detectable by morphological or cytochemical changes after 20 hours, neither did cells of line $\mathrm{L}$ incubated with the dust for three days or eight weeks. There was, however, an arrest of multiplication; after the addition of asbestos (240 to $2400 \mu \mathrm{g} / 10^{6}$ cells) the count was only 40 to $50 \%$ of that of the untreated or corundum-treated controls. About $10 \%$ of the peritoneal macrophages in the control cultures stained with eosin-Y after 20 hours but 50 to $60 \%$ of those incubated with chrysotile and $100 \%$ of those incubated with quartz were stained. These results were confirmed by other morphological and biochemical criteria. The cells incubated with asbestos resembled the untreated controls in showing no diminution in oxygen consumption or lactate synthesis.

This paper gives confirmatory evidence of the effects of chrysotile on monolayer cultures of peritoneal macrophages and shows similar but more evident effects on alveolar macrophages. Four experiments with alveolar macrophages show the same result: eosin-Y uptake and lactic dehydrogenase release is increased by chrysotile as it is by quartz but the lactate production is increased by chrysotile whereas it is decreased by quartz. The tests with peritoneal macrophages are similar but less significant.

The absence of a decrease in the rate of lactate production agrees with the morphological and cytochemical evidence that the chrysotile is not acutely cytotoxic under conditions described in this and in previous papers (Beck et al., 1967b; Beck, 1970).

When the peritoneal macrophages are stained for acid phosphatase 20 hours after incubation with chrysotile has begun, the cells are seen to be actively enclosing the asbestos fibres in lysosomes, which are arranged like a string of beads along the intracellular fibres (Beck et al., 1967b; Beck, Bruch, and Sack, 1967a). There is no sign of the cell damage found after exposure to quartz. Furthermore, no damage can be demonstrated by electron microscopy.

It seems probable that the demonstrable increase in permeability of the cells during the incubation with chrysotile occurs during the phagocytosis of the fibres. While a particle that is approximately spherical is rapidly ingested, the ingestion of a fibre may take many hours, during which time the cell membrane may have a high permeability. For a longer time longer fibres remain partially extra- cellular and, while this condition lasts, cell constituents will diffuse out.

The surface of natural chrysotile probably consists mainly of magnesium ions but partly of silica and, when the asbestos is extracted with acid, magnesium ions are removed leaving a predominantly silica surface (Clark and Holt, 1960, 1961). The form of the adsorption isotherms suggests that the PVNO is adsorbed on the silica sites.

Both the viability and the LDH tests indicate that there is a larger increase in membrane permeability when the acid-treated asbestos is added, to either alveolar or peritoneal macrophages, than when the macrophages phagocytose untreated chrysotile. Lactate synthesis is reduced. This indicates that the acid-treated material increases the permeability of the cell wall to a greater extent than untreated chrysotile, and it is apparently more toxic to cells than is the untreated chrysotile.

In numerous tests it has been proved that, when PVNO and quartz are added together to a cell culture, the quartz behaves as if it were an inert dust, showing little or no cytotoxicity. Chrysotile that had been pre-treated with PVNO produced approximately the same changes in viability test, lactic dehydrogenase release, and lactate synthesis as did untreated chrysotile, and acid-treated chrysotile pre-treated with PVNO gave similar results. Apparently any increase in toxicity caused by the conversion of the chrysotile surface to a silica surface is reversed by PVNO.

One of the early effects resulting from the introduction of chrysotile, amphiboles or glass fibres into the lung is the diapedesis of erythrocytes through the walls of capillaries near to fibres (Botham and Holt, 1968). The observations discussed in this paper show that the act of phagocytosis results in increased permeability of the cell-membrane of the phagocytic cell and it would agree with our observation if the substance affecting capillary permeability were a substance which leaked from the macrophage during the process of phagocytosis. If this were so, it would be expected that some diapedesis of red cells from capillaries would occur during the phagocytosis of any dust but, because the morphology of fibres results in a prolonged period of ingestion, many more erythrocytes would be lost from the capillaries when fibrous dusts are ingested by macrophages. An examination of histological sections of lungs from animals which had inhaled silica dust shows that there is indeed some loss of erythrocytes from capillaries; a few small areas near to the dust give a positive Perls reaction, but the effect is incomparably smaller than when a fibrous dust is inhaled.

\section{References}

Beck, E. G. (1968). Zytologische Untersuchungen über die Partikelaufnahme in vitro. Ein Beitrag zur experimentellen Hygiene. Habilitationsschrift Düsseldorf University. 
- (1970). Die Reaktion in vitro gezuchteter Zellen auf partikel-formige Luftverunreinigungen und hochpolymere Stoffe. Köln Opladen: West deutscher Verlag.-NordrheinWestfalen District Research Report No. 2083.

Beck, E. G., Bruch, J., and Brockhaus, A. (1963). Die Beeinflussung der cytotoxischen Quarzwirkung an Mäusefibroblasten (Strain L) durch Polyvinylpyridin-NOxyd (P 204). Z. Zellforsch., 59, 568-576.

,-- , and Sack, J. (1967a). Beobachtungen über die Morphologie der Staubphagozytose in vitro. Ergebnisse von Untersuchungen auf dem Gebiet der Staub-und Silikosekämpfung im Steinkolhlenbergbau, vol. 6, p. 131-140. Bösmann, Detmold.

, Sack, J., and Bruch, J. (1967b). Die Beeinflussung der cytotoxischen Quarzwirkung an Mäusefibroblasten (Strain L) durch Polyvinylpyridin-N-Oxyd (P 204). In Fortschritte der Staublungenforschung, vol. 2, pp. 481-486. Niederrheinische Druckerei, Dinslaken.

Botham, S. K., and Holt, P. F. (1968). The mechanism of formation of asbestos bodies. J. Path. Bact., 96, 443-453.

Clark, S. G., and Holt, P. F. (1960). Dissolution of chrysotile asbestos in water, acid and alkali. Nature (Lond.), 185, 237.

and - (1961). Studies on the chemical properties of chrysotile in relation to asbestosis. Ann. occup. Hyg., 3, 22-29.
Hanks, J. H., and Wallace, J. H. (1958). Determination of cell viability. Proc. Soc. exp. Biol. (N.Y.), 98, 188-192.

Holt, P. F., Mills, J., and Young, D. K. (1964). The early effects of chrysotile asbestos dust on the rat lung. $J$. Path. Bact., 87, 15-23.

Horn, H. D., and Bruns, F. H. (1956). Quantitative Bestimmung von $\mathbf{L}(+)$-Milchsäure mit Milchsäuredehydrogenase. Biochim. Biophys. Acta, 21, 378.

Koshi, K., Hayashi, H., and Sakabe, H. (1968). Cell toxicity and hemolytic action of asbestos dust. Industr. Hlth (Kawasaki), 6, 69-79.

Parazzi, E. G., Pernis, B., Secchi, G. C., and Vigliani, E. C. (1968). Studies on in vitro cytotoxicity of asbestos dusts. Med. d. Lavoro, 59, 561-575.

Pernis, B., Vigliani, E. C., Marchisio, M. A., and Zanardi, S. (1966). Observations on the effect of asbestos on cells in vitro. Med. d. Lavoro, 57, 721-729.

Sack, J. (1967). Untersuchungen über die Wirkung von Asbeststäuben auf etablierte Mäusefibroblasten (strain L) und primäre Makrophagenkulturen. Dissertation, Düsseldorf University.

Wieland, Th., and Pfleiderer, G. (1957). Nachweis der Heterogenität von Milchsäuredehydrogenasen verschiedenen Ursprungs durch Trägerelektrophorese. Biochem. Z., $329,112$.

Received for publication June 10, 1970. 